JELTIS: Journal of English Language Teaching, Linguistics and Literature Studies

Volume 1. Number 1. August 2021

Available at http://journal.iain-manado.ac.id/index.php/jeltis/index

\title{
English Students' Perception on the Use of Whatsapp Group in Speaking Class
}

\author{
Dhiana Shilvina Salsabila \\ IKIP PGRI Bojonegoro, Bojonegoro, Indonesia \\ dhianashilvina05@gmail.com \\ Meiga Ratih Tirtanawati \\ IKIP PGRI Bojonegoro, Bojonegoro, Indonesia \\ Meigaratihtirtanawati@gmail.com
}

\begin{abstract}
English Students' Perception on the Use of Whatsapp Group in Speaking Class. Online learning is a new policy from the minister of education and culture in the midst of the covid-19 pandemic. It is the first time for english students in IKIP PGRI Bojonegoro do the online learning in speaking class. Speaking is one of the important skills learned in english language. In this era the technology is developing rapidly. Many applications that can support online learning, One of them is whatsapp. Whatsapp is a simple, secure, and reliable messaging application. This research discuss about students' perception on the use of whatsapp group in speaking class. The study aim to find out english students perception on the use of whatsapp group in speaking class and to find out english students challenges on the use of whatsapp group in speaking class. This research includes qualitative research with descriptive qualitative method that describes students' perceptions of using whatsapp groups in speaking class. Based on the qualitative research, it can be seen that the qualitative is used to describe research. The participant of this research was 35 students of the thirth semester of English Education Department academic year of 2020/2021 in IKIP PGRI Bojonegoro. The techniques of collecting data are interview, questionnaire and documentation. In this research researcher analyzed data by data reduction, data display and drawing conclusions. The result show that students perception on the use of whatsapp group in speaking class is less interesting and less effective. Their challenges on the use of whatsapp group are internet connection, feeling bored and lazy, difficult to understand the materials and the time is not according to the schedule. online learning using whatsapp group in speaking class needs more interesting learning activity.
\end{abstract}

Keywords: English Students Perception, Whatsapp Group, Speaking Class 


\section{JELTIS: Journal of English Language Teaching, Linguistics and Literature Studies Volume 1. Number 1. August 2021}

Available at http://journal.iain-manado.ac.id/index.php/jeltis/index

\section{Introduction}

The world is currently experiencing the coronavirus outbreak. Coronaviruses are a large family of viruses that cause illnesses ranging from mild to severe symptoms. On January 30, 2020, WHO has declared it a public health emergency of concern to the world. On March 2, 2020, Indonesia reported its first confirmed case of Covid-19 as many as two cases. The virus that originated in Wuhan, Hubei Province, China has spread rapidly throughout the world. On March 11, 2020, the World Health Organization (WHO) even declared this incident a global pandemic. (Cucinotta \& Vanelli, 2020) It requires us to quarantine at home to break the chain of the spread of the virus. Many sectors in life are also affected by this pandemic. Such as social, economic, and mainly in the education sectors. To overcome the rapid spread of the Covid-19 virus, the Minister of Education and Culture Nadiem Anwar Makarim issued a policy of teaching and learning processes for schools and universities must carry out from home with an online or e-learning system. This is expecting to reduce the interaction of many people, so it can inhibit the spread of the Covid-19 virus. Regarding the impact of the outbreak of Covid-19 virus on the world of education, it requires educators and students quickly adapt to changes. The learning system that was previously based face-to-face directly in the classroom has to change with a virtual learning system through the internet network (online learning). Online learning is a form of distance learning/training that utilizes telecommunications technology and information, for example, the internet, CD-ROM (directly and indirectly) (Abidin \& Arizona, 2020). These situations obliged students to master the technology for online learning. Not only master technology, but they also have to prepare the internet quota and their devices because they must be connected with the lecture at the same time.

Online lectures are one form of using the internet that can increase the role of students in the learning process (Saifuddin, 2018). In this era the technology is developing rapidly, (Costly, 2014) argues that technology is a powerful contributor to learning if it is used to deepen students' engagement in the meaningful and intellectually authentic curriculum. Many applications that can support online learning, one of them is Whatsapp. Whatsapp is a simple, secure, and reliable messaging application. Compared to other applications, the Whatsapp application is classified as the most widely used and familiar. This massaging application lets users text, chat, and share media, including voice messages and video, with individuals or groups. Whatsapp supports group chat that allows you to talk with a group of friends, 


\section{JELTIS: Journal of English Language Teaching, Linguistics and Literature Studies Volume 1. Number 1. August 2021}

\section{Available at http://journal.iain-manado.ac.id/index.php/jeltis/index}

clubs, or any other group. It makes Whatsapp group can be a facility to conduct online learning more easiest. In using Whatsapp groups as a learning medium in the classroom, there are advantages and disadvantages. The advantages are that it can be accessed more easiest, costs are more affordable, study time is flexible. While the disadvantages are limitations of internet access, students tend to be less focused on learning, learning is more theoretical and has minimal practice because it is not possible to have direct interaction with students. Online learning is carried out by almost every educational institution. To break the chain of the spread of the virus and protect the security and safety of students and educators (Zhafira \& Chairiyaton, 2020). IKIP PGRI Bojonegoro has established a policy to implement online learning. In its determination, learning is still carried out but with online learning methods. It is the first time in a speaking class learning using an online system. Speaking is one of four skills in language learning that have to be controlled by the students because these skills directly were linked with all the activities in daily life. It also can be a tool for students to communicate. (Woolf, 1980) states that speaking has a variety of meanings, they are such as: to tell, to say, to make known or as by speaking; to declare; to announce; to proclaim; to celebrate; to use or be able to use (a given language ) in speaking, and to address. The students will speak up their opinion, idea, or asking and getting information through speaking. (Burns, 1998) stated that speaking is a combinatorial language skill. According to (Chaney, 1998) speaking is the process of building and sharing meaning through the use of verbal and non-verbal symbols in a variety of contexts. Speaking is a crucial part of second language learning and teaching. It means that students should communicate with others to get or to share information and to express what they feel. Speaking for most people is considered the most difficult skill because it covers many aspects of English language skills, including pronunciation, listening, grammar, and vocabulary at the same time (Yanto, 2015). In learning the speaking skill, the students need more oral practice so that they can be more confident to speak. Some learning techniques in speaking class such as debates, discussions, seminars, storytelling, etc.

Previous studies on the perception of online learning using Whatsapp groups have been carried out by several studies. The first research on the Students' Perception on the Use of Whatsapp Group for Practicing English by (Salwianto, 2019). This study is a qualitative study, which investigates the student's perception on the use of Whatsapp Group for learning English. This research finds out that there are several benefits of using Whatsapp Group for learning English. They are: Whatsapp 


\section{JELTIS: Journal of English Language Teaching, Linguistics and Literature Studies Volume 1. Number 1. August 2021}

\section{Available at http://journal.iain-manado.ac.id/index.php/jeltis/index}

Group can be used as a means of one of the reachable sources for learning English, Whatsapp Group is considered as one of the best media for practicing English in a relaxed and unstressed situation, Whatsapp group provides partners for practicing students' English skill in writing that will lead to their reading and speaking skill, Whatsapp group gives some valuable feedback for teachers in determining students' error and mistake in sentence construction, Whatsapp group enable the teacher to provide a direct situation in correcting students' error and mistake. The second research is about Students Perception of the Use of Whatsapp Applications to enhance communicative skills by (Nurul Aiman Binti Mohd Jafre, 2018). The process of data collection is done by using a qualitative method in where the semi-structured interview was conducted. The interview was conducted to gain deeper explanations on students' perception towards learning communicative skills using the Whatsapp application. The result of the research shows that the use of this application does not only increase the interest and motivation for students to learn, but it also provides them larger opportunities to practice their communicative skills without being limited with the time and classroom meetings. More importantly, as Whatsapp is one of the mobile technologies closely related to the students' interest, it can make students excited to carry out the activities and subconsciously reduce their anxiety problem. Apart from that, this tool also helps to build their self-confidence, passion in learning and explore their learning ability.

The third research is on Students' perception on the Use of Whatsapp Applications in Teaching of English at Eight Grade Students of Madrasah Tsanawiyah Nurul Hidayah Bhakti Idaman Tanjab Timur Jambi by (Mardiah, 2020). The study aimed to find out the students' perception on the use of Whatsapp application in the teaching of English at eight grade students' of Madrasah Tsanawiyah Nurul Hidayah Bhakti Idaman Tanjab Timur Jambi. Based on the result of the research, the researcher found that students' perception on the use of Whatsapp application in the teaching of English that the students who think learning English use Whatsapp application does not give maximum results. Some students said that it was difficult to understand the teaching material provided by the Whatsapp application. Whatsapp application was less able to help in the teaching and learning process of English lessons.

The research conducted by the researcher is slightly different from the four previous studies because this research focuses on the use of Whatsapp groups in speaking class at third-semester students of the English Department of IKIP PGRI 


\section{JELTIS: Journal of English Language Teaching, Linguistics and Literature Studies Volume 1. Number 1. August 2021}

\section{Available at http://journal.iain-manado.ac.id/index.php/jeltis/index}

Bojonegoro. This is because researchers need information from students about learning in the speaking class on use the Whatsapp group to improve learning in the speaking class in the next semester so that the lecturer can get a reference for the implementation in the next lesson. Speaking is one of two kinds of productive skills besides writing. (Nunan, 2003) stated that speaking is the productive aural/oral skill. It consists of producing systematic verbal utterances to convey meaning. Moreover, Longman stated that speaking is defined as to be able to talk in a particular language. Similarly, speaking is defined as to be able to use language. It can be concluded that speaking is an ability of a person to express their ideas, feelings or something in their minds to others. According to Richard and Renandya, the learners study English in order to develop their language ability in speaking. Speaking is used for various purposes that are to express opinion, to describe something, to complain about something, to persuade someone, or to make polite requests. The intention of speaking course is often that the students should be able to express them self in the target language; to cope with basic interactive skill like exchanging greetings, thanks, and apologies; and to express their need, request information, service and etc. It means that students should master the language components, if students can master these components, they will not have difficulties to express their ideas, thought and feeling. Whatsapp is particularly popular because its enhanced capabilities allow users to interact in a variety of ways. For example, whatsapp allows users to exchange text messages one-to-one or as group conversations. Additionally, users can share documents and a variety of multimedia types as well as making voice or video calls. With this functionality, whatsapp is a useful learning tool that makes posting, sharing content and engaging in online discussions easy and available anywhere and anytime (Luaran Johan, 2016).

The research questions of this study are what is english students perceptions on the use of Whatsapp group in speaking class? What is English students challenges on the use of Whatsapp group in speaking class? those questions will be answered in this research. Based on the research questions above, the objectives of this research are to find out english students perceptions on the use of Whatsapp group in speaking class and to find out english students challenges on the use of Whatsapp group in speaking class. The researcher expected that this research will be beneficial to the lecturer, english students, and future researchers. first is to the lecturer, this research expects that the lecturers can see whether Whatsapp group discussion is effective or ineffective enough to be used as a learning media in speaking class. The 
JELTIS: Journal of English Language Teaching, Linguistics and Literature Studies Volume 1. Number 1. August 2021

Available at http://journal.iain-manado.ac.id/index.php/jeltis/index

second is for english students, It is expected that this research will help the students to express their feeling so far while studying using a Whatsapp group in speaking class. the third is for future Researchers, the researcher hopes that the result of this study may give a positive contribution in using Whatsapp group in speaking class and can be a reference for other studies which are related to this topic.

\section{Methodology}

In this research the researcher want to find out the information about english students perception and english students challenges on the use of whatsapp group in speaking class. In this case the researcher will use the design descriptive qualitative. According to (Ary, 2002) descriptive research is studies are designed to obtain information concerning the current status phenomena. In qualitative research, there is a little or no statistic. According to (Patton, 2012) qualitative research is characterised by it is aims, which relate to understanding some aspect of social life, and it is methods which (in general) generate words, rather that numbers, as data for analysis. It means, which relates to understanding some aspects of social life, and uses the method of words not numbers.

This research was conducted in IKIP PGRI Bojonegoro. The location of this Bojonegoro Teacher Training and Education Institute is in Panglima Polim street no. 46 Bojonegoro. The participants of this research is 35 students of English students of the third semester of English Education Department in 2020/2021 academic year. The students of the third semester of English Education Department in 2020/2021 academic year are 30 female and 5 male.

The sources of data in this study consists of two types, namely primary and secondary. The primary data in this study is the result of an open-ended questionnaire. The data in this study were obtained directly from students majoring in English education in the third semester at IKIP PGRI Bojonegoro for the 2020/2021 academic year. The primary data of this questionnaire was obtained through a questionnaire that had been given to informants online via google form. The Secondary data obtained from secondary sources of data that researchers need. Secondary data in the form of data that is already available and can be obtained by researchers by reading, viewing or listening. Secondary data in the form of interviews and documentation. Secondary data by interviews were obtained by directly interviewing third semester students majoring in english education at IKIP PGRI 
JELTIS: Journal of English Language Teaching, Linguistics and Literature Studies Volume 1. Number 1. August 2021

Available at http://journal.iain-manado.ac.id/index.php/jeltis/index

Bojonegoro for the 2020/2021 academic year using semi-structured interviews. Secondary data documentation is obtained from the screen capture of the whatsapp group in learning in the speaking class. The essential differences in usage between questionnaires and interviews that researchers conducted for the study is interviews as secondary data to minimize misunderstandings of students' answers in the questionnaire and to obtain answers in more depth.

The researchers use some techniques in collecting the data. Those are interview, questionaire and documentation. The type of interview used is a semistructured interview. The reseacher used this type of interview because the researcher want to find problems more openly and in-depth. The interview consist of fifeteen question. Interview questions were taken from the questionnaire, with additional questions to support the data obtained. The technique used are recording, rewriting, summarizing, and analyzing data. Interviews were conducted with 8 english students. In conducting interviews, Indonesian is used to facilitate third semester english students answering questions. After that, the researcher translated the results of the interview in English. The research questionnaire consisted of ten open-ended questions. The reseachers used open-ended questionnaire because the reseachers want to obtain broad and in-depth answers. The questionnaire were given to 35 students. To make it easier for students to fill in, the questionnaire was prepared using indonesian language. The researcher made an electronic questionnaire in the form of a Google Form, then distributed it to groups of whatsapp third semester english students of IKIP PGRI Bojonegoro. The researcher also collecting the data using documentation. The documentation in this study is in the form of screen captures of learning activities in the speaking class using the whatsapp group. In this study the researcher used three step in anlyzing the data. The first is data reduction. Data will be selected and reduced so that only relevant data is used. The second is data display. Data display is the process of presenting data after data reduction. The presentation of data in qualitative research is carried out in the form of summaries, charts, relationships between categories, patterns, and others so that it is easily understood by the reader. And the third is conclussion. The conclusions of the results of the study must be able to provide answers to the formulated problems. 
JELTIS: Journal of English Language Teaching, Linguistics and Literature Studies Volume 1. Number 1. August 2021

Available at http://journal.iain-manado.ac.id/index.php/jeltis/index

\section{Findings}

\section{English Students Perception on The Use of Whatsapp Group in Speaking Class}

This sub bab will contains of students' perception of the speaking class process using the whatsapp group, students' perceptions are related to the motivations in learning speaking using whatsapp group, students' perception about speaking abilities improvement in learning speaking using whatsapp group, student perception related to the effectiveness of learning speaking using whatsapp group, students' perception related to the advantages of speaking learning using whatsapp group during the covid-19 pandemic, and student perception related to the disadvantages of speaking learning using whatsapp group during the covid-19 pandemic.

Based on the result of questionnaires result about students' perception of the speaking class process using the whatsapp group there are two kinds of answers. There are positive perception and negative perception from students. The percentage of students who have a positive perception is $52,2 \%$ and the percentage of students who have negative perceptions is $47,8 \%$. Students who have a positive perception of the speaking class process using the whatsapp group argue that the process is systematic. The lecturer invites students absent, then the lecturer provides an explanation of the material and gives assignments. Tasks that have been given are asked to be sent via another platform. Students who have negative perceptions about the speaking class process using the whatsapp group argue that the process is complicated, not satisfactory, and ineffective because learning is done indirectly and students activity is very minimal so that communication between lecturers and students is hampered.

The results of the questionnaire are supported by answers from interviews. To make it easier to analyze the answers from 8 students, the researcher categorizes the answers that most often arise from the informants. The first category is only send materials and assignments. There are 3 informants who say that the learning process in speaking class uses whatsapp group is only send materials and assignments.

Student : "Langsung diberi materi dan tugas"(Immediately given the material and assignments) 


\section{JELTIS: Journal of English Language Teaching, Linguistics and Literature Studies Volume 1. Number 1. August 2021}

\section{Available at http://journal.iain-manado.ac.id/index.php/jeltis/index}

The second category is absent, give materials and assignments. There are 5 informants who say that the learning process in speaking class uses whatsapp group is first absent, than the lecturer given the materials and assignments.

Student : "Pertama absen, kemudian diberi materi dan tugas tugas"( First absent, then given the material and assignments)

Based on the result of questionnaires result about students' perceptions are related to the motivations in learning speaking using whatsapp group. There are two perception of students. The first perception is the use of whatsapp group in speaking learning is motivated and the second perception is the use of whatsapp group in speaking learning is not motivated. There are 39,1\% students answer the use of whatsapp group in speaking learning is motivated. They argue that they motivated to study seriously by using whatsapp group in speaking class. they also feel motivated because they can hone their ability to speak slowly by not speaking in front of many people directly. Students feel motivated to learning speaking when the lecturer gives the assignment to make videos by speaking english. There are $60,9 \%$ students answer the use of whatsapp group in speaking learning is not motivated. They argue that learning speaking using whatsapp grub is not motivating because it is boring and doesn't understand the material presented.

The results of the questionnaire are supported by answers from interviews. To make it easier to analyze the answers from 8 students, the researcher categorizes the answers that most often arise from the informants. First category is motivated. There are 4 informants who say that learning speaking uses whatsapp group is make them motivated in learning in speaking class.

They feel motivated because they should not speak in front of many people and sometimes the lecturer share videos that related to the assignment.

Student: "lya, karena saya adalah orang yang pemalu dan kurang percaya diri untuk berbicara di depan banyak orang. Jadi saya merasa termotivasi belajar speaking menggunakan grup whatsapp"(Yes, because i am a person who is shy and lacks confidence to speak in front of many people. So I feel motivated to learn speaking using the whatsapp group.)

The second category is does not motivated. There are 4 informants who say that learning speaking uses whatsapp groups is does not motivated. It is because there is not much interaction between lecturers and students. 
JELTIS: Journal of English Language Teaching, Linguistics and Literature Studies Volume 1. Number 1. August 2021

Available at http://journal.iain-manado.ac.id/index.php/jeltis/index

Student: "Tidak, karena tidak ada banyak interaksi antara dosen dan mahasiswa"( No, because there is not much interaction between lecturers and students)

Based on the result of questionnaires result about students' perception about speaking abilities improvement in learning speaking using whatsapp group, there are three kinds of answer. That are learning speaking skill using whatsapp grub can improve speaking ability, learning speaking skill using whatsapp grub can not improve speaking ability, and neutral. The percentage of students who have answer that learning speaking skill using whatsapp group can improve speaking ability is $39,1 \%$. They argue that it can improve speaking ability because they become more confident in speaking and the assignment given by the lecturer in the form of making videos can also improve their speaking skills.. The percentage of students who have answer that learning speaking skill using whatsapp grub can not improve speaking ability is $52,2 \%$. They argue that it can not improve their speaking ability because they feel there is a lack of interaction with fellow friends and for speaking learning there is less practice. The percentage of students who have neutral perception is $8,7 \%$. according to them, speaking learning using the whatsapp group may can or may can not improve speaking skills depending on the person and material presented.

The results of the questionnaire are supported by answers from interviews. To make it easier to analyze the answers from 8 students, the researcher categorizes the answers that most often arise from the informants. First category can improve speaking skill. There are 5 informants who say that learning speaking uses whatsapp group can improve speaking skllis. according to them it can improve speaking skill if there is a desire, try and do not ashamed to ask.

Student: "Bisa, jika berusaha dan tidak malu untuk bertanya"(Yes, if you try and are not ashamed to ask.)

The second category can not improve speaking skill. There are 3 informants who say that learning speaking uses whatsapp groups is can not improve speaking skill. It is because speaking is related to the ability to speak in english while in the whatsapp group only material was given and there is not much practice in grub whatsapp.

Students: "Tidak, karena speaking berkaitan dengan kemampuan berbicara dalam bahasa inggris sedangkan di grub whatsapp hanya diberikan materi saja"( 
JELTIS: Journal of English Language Teaching, Linguistics and Literature Studies Volume 1. Number 1. August 2021

Available at http://journal.iain-manado.ac.id/index.php/jeltis/index

No, because speaking is related to the ability to speak in english while in the whatsapp group only material was given)

Based on the result of questionnaire about student perception related to the effectiveness of learning speaking using whatsapp group, there are two kinds of answers. They are effective and ineffective. There are 30,4\% students answer that learning speaking using whatsapp group is effectives. They argue that the use of group WhatsApp in the speaking class is effective because it can interact in groups, is more familiar to students, to prevent the spread of covid-19, does not consume a lot of internet quota and students are really monitored by lecturers so they cannot hide from all assignments. There are $69,6 \%$ students answer that learning speaking using whatsapp group is ineffectives. They argue that the use of whatsapp groups in the speaking class is not effective because they cannot fully understand the speaking material, it is boring, uninteresting, and the communication between lecturers and students is hampered either because students are lazy or lecturers' responses are not as fast as face-to-face learning.

The results of the questionnaire are supported by answers from interviews. To make it easier to analyze the answers from 8 students, the researcher categorizes the answers that most often arise from the informants. the first category is effective. There are 1 informants who say that learning speaking uses whatsapp group is effective.

Student: "Lumayan efektif"( Fairly effective)

The second category is does not Effective. There are 7 informants who say that learning speaking uses whatsapp groups is not effective

Student: "Kurang efektif, karena pembelajaran kurang menarik dan mahasiswa pasif"(Less effective, because learning is less attractive and students are passive)

Based on the result of questionnaires result about students' perception related to the advantages of speaking learning using whatsapp group during the covid-19 pandemic, there are several advantages of using whatsapp groups in learning speaking based on students' answers in this open questionnaire. The first advantantages is easy. It can be seen from the precentage $17,4 \%$ from $100 \%$ students answer that the advantages of speaking learning using whatsapp is easy. The second $8,7 \%$ precentage of students who has answer that the advantages is familiar. Third $17,4 \%$ of students answered that the benefits of learning in the speaking class using 


\section{JELTIS: Journal of English Language Teaching, Linguistics and Literature Studies Volume 1. Number 1. August 2021}

\section{Available at http://journal.iain-manado.ac.id/index.php/jeltis/index}

the whatsapp group is that they were free to express themselves. Fourth, the next advantages according $8,7 \%$ percentage of students answer that the advantage is learning activities become more relaxed. Fifth, 17,4\% percentage students answer that the advantage is economical, neat and systematic and 30,4\% percentage students answer there is no advantages.

The results of the questionnaire are supported by answers from interviews. According to interview result, there are several advantages on the use of whatsapp group in speaking class. First the application does not wasteful on quotas. Second materials and videos can be viewed whenever needed. Third, the time is flexible. Fourth, more confident. Fifth, can improve learning. Sixth, can send documents, photos, audio, videos as learning materials, repeat material via cellphone easily and communicate anywhere and anytime. Seven, the application is lightweight, saves quota and all students can use it. Eighth, More fun.

Students: "Tidak boros kuota"( Not wasteful on quotas)

Based on the result of questionnaires result about student perception related to the disadvantages of speaking learning using whatsapp group during the covid-19 pandemic. Students answered that there were several disadvantages in learning to speak using the whatsapp group. First, 17,3\% of students answered that the disadvantages was a little interaction. Second, $8,7 \%$ of the student's persentage answered that the drawback was a little practice. Third, there is a 4,4\% persentage of students who answer that learning in the speaking class using the whatsapp group is uncomfortable. Fourth, the disadvantages is poor internet connection with $21.7 \%$ percentage of students answering. Fifth, 4,4\% of students answered that the deficiency was difficult. Sixth, 30,4\% of students' answered that the drawback was that the lecturers did not explain the material in detail. Seventh, 4,4\% of the students' persentatage answered that there were many deficiencies and 4,4\% answered that there were no disadvantages.

The results of the questionnaire are supported by answers from interviews. According to interview result, there are several advantages on the use of whatsapp group in speaking class. First, can not be much mastered the material. Second, makes students lazy and lacks practice when using whatsapp groups. Third, Not according to the schedule. Fourth, Students are less active when learning using the whatsapp group. Fifth, Lack of interaction. Sixth, Tasks cannot be organized systematically and 
JELTIS: Journal of English Language Teaching, Linguistics and Literature Studies Volume 1. Number 1. August 2021

Available at http://journal.iain-manado.ac.id/index.php/jeltis/index

memory fills up quickly. Seventh, we cannot respond to each other using voice just typing. Eighth, Less use of existing features in whatsapp and less frequent practices.

Student: "Membuat mahasiswa malas dan kurang ada praktik ketika meggunakan grup whatsapp"(Makes students lazy and lacks practice when using whatsapp groups)

\section{English Students Challenges on The Use of Whatsapp Group in Speaking Class}

This sub bab will be answered the second research question stated in research problem. This part consist of english students challenges on the use of whatsapp group in speaking class. Based on the result of questionnaires there were several challenges that have been experienced by students on using whatsapp group in speaking class. First, there are $8,7 \%$ students answer that their challenge is missunderstanding the materials. The second 4,4\% students answer that their challenges is feeling lazy to learn. Third, the precentage 30,4\% from 100\% answer that their challenge is difficult to understand the material so that sometimes misunderstandings arise. Four, 8,7\% students answer their challenge is the hours of speaking class that is not according to the schedule. Fifth, 17,4\% perecentage of $100 \%$ percentage students answer there are many challenges and 4,4\% students answer that there are no challenges.

The results of the questionnaire are supported by answers from interviews. According to interview result there are several challenges that the students are faced. First, can not be much mastered the material. Second, makes students lazy and lacks practice when using whatsapp groups. Third, Does not according to the schedule. Fourth, students are less active when learning using the whatsapp group. Fifth, Lack of interaction. Sixth, tasks cannot be organized systematically and memory fills up quickly. Seventh, we cannot respond to each other using voice just typing. Eighth, less use of existing features in whatsapp and less frequent practices.

Student: "Membuat mahasiswa malas dan kurang ada praktik ketika meggunakan grup whatsapp"(Makes students lazy and lacks practice when using whatsapp groups) 
JELTIS: Journal of English Language Teaching, Linguistics and Literature Studies
Volume 1. Number 1. August 2021

Available at http://journal.iain-manado.ac.id/index.php/jeltis/index

\section{Discussion}

Whatsapp application is used as an application that helps students in the learning process in speaking classes during a pandemic. In this case the researcher has conducted research through interviews, questionnaires and supported by documentation to find out the perception of english students about the use of whatsapp groups in speaking class and the challenges of english students on the use of whatsapp groups in speaking class.

Based on the results of research conducted from April to May 2021 on third semester students at IKIP PGRI Bojonegoro by conducting interviews and providing questionnaires that the researchers have described, and supported by documentation, it can be seen that students' perceptions of the learning process in the speaking class using whatsapp are a process of learning in speaking class is systematic. at the beginning of learning the lecturer greets and invites students to be absent, the lecturer delivers the material, then gives assignments and assignments are collected through other platforms. Utilizing whatsapp as an online learning medium to support the learning process while at home in accordance with the policies issued by the Minister Nadiem Anwar Makarim who issued Circular Letter Number 36962/MPK.A/HK/2020 concerning "Learning Online (In the Network) in order to prevent the spread of Corona Virus Disease (COVID-19)". This policy enforces the learning process from home with the help of distance learning media, one of which is the use of whatsapp that has implemented in speaking class. Learning activities are accessed via whatsapp such as the delivery of materials, information, and assignments that are carried out by utilizing the video and document features.

According to (Rusman, 2018) that learning media can arouse the enthusiasm and motivation of students, but based on the results of interviews and open-ended questionnaires conducted with informants, it was found that most of their perceptions on the motivation in speaking class using whatsapp, students felt less motivated. The practice of speaking is not directly, the learning make the students feel boring, and they don't really understand the material presented are the reason why they argued less motivated on the use of whatssapp group in speaking class. such as the findings of Wiji Lestari's research which shows that there is a lack of student motivation in using Whatsapp as an online learning medium. (Lestari, 2021) 
JELTIS: Journal of English Language Teaching, Linguistics and Literature Studies Volume 1. Number 1. August 2021

Available at http://journal.iain-manado.ac.id/index.php/jeltis/index

Based on the results of interviews and open questionnaires, the speaking ability of students in the speaking class did not increase. The reason for their perception is that the first is due to the lack of interaction, both interaction between teachers and students, as well as students and their friends. According to (Pane, 2017) that learning and learning activities are an educational interaction process in order to achieve educational goals. while the second reason is lack of practice. According to them, speaking material using whatsapp groups can be directly practiced using the voicenote feature.

Furthermore, data from interviews and questionnaires revealed students' perceptions about the effectiveness of using whatsapp grub in speaking class. This data refers to the category of student answers that are less effective. The reason for the student's perception is because they feel learning is less interesting. such as the research findings of Mirzan dkk which show that online learning through Whatsapp tends to be ineffective. (Mirzon Daheri, 2020)

There are many features in the whatsapp application as a learning medium that can be used By teachers as described in chapter II to make learning more interesting. According to Nasution, the benefits of learning media as a tool in the learning process are as follows: teaching attracts more students' attention so that it can foster learning motivation, teaching materials will have a clearer meaning so that they can be understood better, and enable students to master teaching objectives well, varied learning methods, not only communication verbally through the spoken words of the teacher, students are not bored, and teachers do not run out of energy.

From interview data and questionnaires revealed students' perceptions about the advantages on the use of whatsapp group in speaking class. there are several advantages that students convey. First is save quota. such as the findings of Hana's research which shows that the advantage of using whatsapp for learning is that it saves internet quota. (Azizah, 2021) Second the timing is flexible. Third, be more confident. Fourth, can send documents, photos, audio, videos. Fifth it is easy. Sixth, the application is familiar.

If there are advantages there must be disadvantages. the data from the questions on the questionnaire and the interview revealed the disadvantages on the use of whatsapp group in speaking class. there are several disadvantages conveyed 


\section{JELTIS: Journal of English Language Teaching, Linguistics and Literature Studies Volume 1. Number 1. August 2021}

\section{Available at http://journal.iain-manado.ac.id/index.php/jeltis/index}

by students, namely lack of interaction, lack of practice, not on schedule, students are less active, memory full fastly, lack of use of features in the whatsapp group, and the lecture did not explain in detail.

Data from questionnaires and interviews revealed the english students challenges on the use of whatsapp group in speaking class. there are several difficulties faced by students during online learning in speaking classes using whatsapp group. First, the internet connection. This is because the first factor is the location of student houses in rural areas, causing internet connections to be disrupted. The next factor is when online learning occurs and the lights go out or other factors that make the signal slow. Second, feeling bored and lazy. This means that their challenges during learning in speaking class using whatsapp group is a sense of laziness and boredom that arises due to learning that is less interesting and varied. Such as the findings of the lesi research which showed that the perception of students in online learning using whatsapp was that students felt saturated or bored when carrying out online learning due to the lack of variation in learning such as the presence of images, sounds, and text as material explanations (Amiroh, 2020). Third, difficult to understand the material. Students feel that the challenges they face when learning online is that it is difficult to understand the material that has been delivered by the lecturer. Online learning, which is a new product in the midst of the COVID-19 pandemic, is a challenge in itself. For some students, the online learning system that they have just experienced is not as effective as the face-to-face system, especially for students whose reasoning power and intellectual ability are lacking, cannot ask the teacher face-to-face if there is subject matter that they do not understand (Rustiar Efendi, 2020). such as the findings of the Nindia's research which shows that there is a lack of understanding of students when doing the online learning process. This is because students do not understand the learning taught by the teacher because they do not meet face to face. (Nindia Taradisa, 2020). Fourth, speaking class hours that are not according to the schedule. It means that their challenge is speaking class hours that are not in accordance with the schedule. This makes them have to be able to manage time because at home they are also faced with various homework. No matter how difficult the online learning process is and the emergence of several challenges in its implementation, it cannot be denied that online and distance learning is a necessity to maintain social distance due to the Covid-19 pandemic. (Ali, 2020) 
JELTIS: Journal of English Language Teaching, Linguistics and Literature Studies Volume 1. Number 1. August 2021

Available at http://journal.iain-manado.ac.id/index.php/jeltis/index

There are some limitations to this study. Those are, first, this study focuses on English students' perception on the use of whatsapp group in speaking English students' challenges on the use of Whatsapp group in speaking class. Second, the researcher did an interview and shared questionnaires with the third-semester students in english education major. For the next researcher, the researcher suggest to investigate the teacher perception on the use of whatsapp group in speaking class because whatsapp group is a new application as learning media in learning speaking english. Each English teacher has a different perception about whatsapp group as learning media in learning speaking english. The researcher suggests the next researcher finds out the teacher perceprtion about the use of whatsapp group in speaking class and teacher challenges on the use of whatsapp group in speaking class. It gives a strong statement on what is the teacher perception and challenges on the use of whatsapp group in speaking class

\section{Conclusion}

English students perception on the use of whatsapp group in speaking class is that students feel that the use of whatsapp group in speaking class is less interesting, resulting in a lack of motivation in learning and they cannot be maximally involved in the learning process as they cannot communicate directly with the teacher when there is the material that has not been understood. And their perception of learning is less effective due to a lack of interaction and practice. English students challenges are an internet connection, feeling bored and lazy, difficulty to understand materials, and the time is not according to the schedule.

\section{Suggestion}

Based on the previous conclusion, the researcher would like to give some suggestion about the english students perception on the use of whatsapp group in speaking class and english student challenges on the use of whatsapp group in speaking class. Hopefully, the suggestion adds knowledge for the teacher that perception is an important role because it influences the students thinking, feeling and motivation in learning speaking. The researcher suggest to the teacher to use the more interesting learning activity in speaking class. It is also suggested that the teacher should be more interactive in teaching so that the students are not bored in 
JELTIS: Journal of English Language Teaching, Linguistics and Literature Studies Volume 1. Number 1. August 2021

Available at http://journal.iain-manado.ac.id/index.php/jeltis/index

following the teaching-learning activity. With the difficulty of understanding the materials, the teacher can convey a detailed explanation about the material.

For the english students in IKIP PGRI Bojonegoro there are some suggestion. First, they should concentrate more in learning process, because speaking is one of the important skill in learning english. Second, they also should more active in learning process.

For the next researcher, who want to conduct research with the same subject, the result of the research can be used as an additional reference or further research with different discussion.

\section{References}

Abidin, Z., \& Arizona, K. (2020). Pembelajaran Online Berbasis Proyek Salah Satu Solusi Kegiatan BelajarMengajar Di Tengah Pandemi Covid-19. Jurnal Ilmiah Profesi Pendidikan, 5(1), 64-70.

Ali, W. (2020). Online and Remote Learning in Higher Education Institutes: A Necessity in Light of Covid 19 Pandemic. Higher Educatin Studies, 10(3), 16.

Amiroh, L. (2020). Persepsi Siswa Terhadap Penggunaan media sosial Whatsapp pada Pembelajaran Secara Daring di Masa Pandemi Covid-19. Repository UNJA.

Ary, D. (2002). Introduction to Research Education. USA: Wadsworth Group A Division Of Thompson Learning Inc.

Azizah, H. M. (2021). Pemanfaatan Media Sosial Whatsapp Sebagai Ruang Pembelajaran Fikih kelas VII di MTS Darus Sholichin Kota Malang. etheses UIN Malang.

Burns, A. (1998). Teaching Speaking. Anual Review of Applied Linguistics, 18, 102103.

Chaney, A. L. (1998). Teaching Oral Communication. Boston: Allyn and Bacon.

Costly, K. C. (2014). The Positive Effect of Technology on Teaching and Student Learning. ARKANSAS University.

Cucinotta, D., \& Vanelli, M. (2020). WHO declares Covid-19 a pandemic. Acta Biomedica, 9(1), 157-160.

Lestari, W. (2021). Pemanfaatan Whatsapp Sebagai Media Pembelajaran Dalam Jaringan Masa Pandemi Covid-19 dikelas VI Sekolah Dasar. Repository Universitas Jambi. 
JELTIS: Journal of English Language Teaching, Linguistics and Literature Studies Volume 1. Number 1. August 2021

Available at http://journal.iain-manado.ac.id/index.php/jeltis/index

Luaran Johan, J. J. (2016). The use of whatsapp group in class-related information sharing through academic discussion. International Journal on E-learning and Higher Education, 176-194.

Mardiah, S. (2020). Students' perception on the Use of Whatsapp Applications in Teaching of English at Eight Grade Students of Madrasah Tsanawiyah Nurul Hidayah Bhakti Idaman Tanjab Timur Jambi. Repository UIN Sulthan Thaha Saifudin.

Mirzon Daheri, J. J. (2020). Efektifitas WhatsApp sebagai Media Belajar Daring. Jurnal Basicedu, 4(4).

Nindia Taradisa, N. J. (2020). Kendala yang dihadapi Guru Mengajar Daring pada masa pandemi covid-19 di MIN 5 Banda Aceh. Repository AR-Raniry, 1-11.

Nunan, D. (2003). Practical Language Teaching. New York: McGraw-Hil.

Nurul Aiman Binti Mohd Jafre, N. B. (2018). The second research is about Students Perception of the Use of Whatsapp Applications to enhance communicative skills. International Journal of Education, Islamic Studies and Social Science Research, 3(1).

Pane, D. (2017). Belajar dan Pembelajaran. Jurnal Kajian Ilmu-ilmu Keislaman, 3(2), 333-352.

Patton, M. Q. (2012). A guide to using qualitative research methodology. Medicins Ssns Frontieres, 7(3), 1-36.

Rusman. (2018). Belajar dn Pembelajaran Berbasis Komputer. Bandung: Alfabeta.

Saifuddin, M. F. (2018). E-Learning Dalam Persepsi Mahasiswa. Jurnal VARADIKA, 29(2), 102-109.

Salwianto, K. R. (2019). The Students Perception on the Use of Whatsapp Group for Practicing English. Prociding ELTIC 2019.

Yanto. (2015). Belajar Bahasa Inggris Melalui Media. Diambil kembali dari Kompasiana: http://www.kompasiana.com/yantomed/belajar-bahasaInggris-melaluimedia_5516fad3a333110970ba8f2d

Zhafira, N. H., \& Chairiyaton. (2020). Daring Sebagai Sarana Pembelajaran Selama Masa Karantina Covid-19. Jurnal Bisnis dan Kajian Manajemen, 4(1), 37-45. 